Marko Čudić

Faculty of Philology

University of Belgrade
UDC 821.511.141(497.11)

DOI https://doi.org/10.18485/fid.2017.7.ch13

\title{
THE PHENOMENON OF DELIBERATE "LANGUAGE LOSS" IN THE WORKS OF ISTVÁN DOMONKOS AND LÁSZLÓ VÉGEL
}

У основи постоје два различита односа према употреби језика када су у питању мањинске књижевности. Први, конзервативнији, обележен је амбицијом да се очува „угрожени“ језик, док други, који је углавном присутан у модерним и савременим делима, покушава, на нешто парадоксалнији начин, да створи свој свет помоћу потпуно новог, наизглед „сиромашног“ и ограниченог језика који је сачињен од елемената заједничког језика у мањинској заједници. Овај језик, међутим, понекад има мало или готово никакве везе са „правим“, говорном језиком припадника једне заједнице. Овај рад се бави феноменом „намерног губитка језика“ у два истакнута дела мађарског песника из Војводине, Иштвана Домонкоса, и прозног писца из Војводине, Ласла Вегела. У раду се истичу и главне разлике у манифестовању овог феномена у поезији и прози.

Кључне речи: мањинска књижевност, намерни губитак језика.

The appearance of the neo-avantgarde literary magazine Új Symposion in Novi Sad in the early 1960s marked a genuine poetical revolution in the literature of the Hungarians living in Vojvodina (then part of Yugoslavia). A magazine with such a revolutionary approach to literature and art in general, surely would not have been met with approval even in a country with a far more liberal cultural policy than in the socialist Yugoslavia of the time. Especially bearing in mind the fact that the struggle of the artists who gathered around the magazine - Ottó Tolnai, Katalin Ladik, István Domonkos, János Sziveri, Béla Csorba, as well as the somewhat younger Attila Balázs, Magdolna Danyi and others - was not only a struggle against the single-mindedness of the (communist) regime and the stupidity of its hypocritic phrases; it was also a fight for a brand new poetics. And although the restraints of the zhdanov doctrine and of the aligned, socrealistic approach to literature had already significantly loosened in the 50 's (it is enough to mention the well known speech by Miroslav Krleža 
at the Writers Congress in Ljubljana in 1952), the main goal for which the symposionists from Novi Sad were fighting for was indeed a radical breakup with the poetical tradition of Hungarian literature in the first place (not specifically with the tradition of Hungarian literature in Vojvodina as a minority literature, but of the tradition of Hungarian literature as a whole, since the ambitions of the Novi Sad symposionists was not only to harshly and mercilessly criticize and ridicule the provinciality of the minority existence and minority art; their ambitions were much higher, they targeted the very peaks of Hungarian literature as such).

In Hungarian literature, according to a tradition set by the works of illustrious artists gathered around the famous Nyugat literary magazine published in Budapest in the first half of the twentieth century, poetry has been considered as the emanation of beauty, where the poems needed to be molded into some expected metrical patterns ( iambic verse and rhymes were almost always considered obligatory). However, one of the most significant symposionists, Ottó Tolnai (b. 1940), with his blank verses, with the omission of punctuation and capitalization, with his specific rhythmic way, different from the (then) obligatory iamb, as a prominent Hungarian literary scholar from Vojvodina, János Bányai (2015: 57) points out, "blew up" undermined a whole stable, and, it seemed until then, unquestionably formal concept of Hungarian poetry, based on mandatory rhymes and iambic metrical schemes. The artists who gathered around this revolutionary magazine realized that the only way they could break into the bloodstream of Hungarian literature, the "real" one, i.e. the one that was nourished on a great (or less great) level in their native country, was to introduce some quite radical innovations into their language, rather than sticking to the old and conservative path of provincial lamentations (both in verse and in prose) with a high degree of self-victimization. The poetics of the authors associated with this magazine has left such a deep mark in the history of newer Hungarian literature, that the critical and theoretical approach to their works has already become an integral part of basically all university curricula where departments of Hungarian Language, Literature and Culture exist, both as mother or foreign tongues.

According to a Hungarian scholar from Slovakia, Zoltán Németh, there are basically two different operation modes of minority literature 
(he was writing about the situation of Hungarian literature in Slovakia, however, his observations, it appears, could, to some extent, be applied to the situation of Hungarian literature in Vojvodina as well). In the first case, literature is considered as a mere channel through which a specific minority community sings about their "sorrow" - and, since this type of writing requires a relatively simple and straightforward way of announcing certain information, it is quite obvious that this type of literature has little chance of attaining high aesthetic value. The other path, which is, speaking strictly from a literary point of view, a much harder one, is the, so to say, zarathustrian path of "breaking the tables". It is, most importantly, the path of (mostly) applying language and stylistic innovations, using much more complicated lyrical or narrative structures; thus, it is a path of trying to create more stratified writings with higher artistic value, as Roland Orcsik (2015: 20), relying on Zoltán Németh's main framework, points out. Obviously, the symposionists are representatives of this letter, more innovative path.

The first of the aforementioned approaches to (minority) literatures aims mostly at preservation, conservation of the language at a given state (since the moralistically and didactically oriented representatives of this aesthetical stream are worried about the mere survival of their language under linguistical and political "majority terror"). The representatives of the latter, aesthetically much more demanding tendency, sometimes act, however, in exactly the opposite way: their writings at times even tend to reflect a specific type of deliberate and tendentious loss of the (native) language. As for the Hungarian literature in Vojvodina, the most radical changes in this field were introduced by Katalin Ladik and István Domonkos in poetry, and László Végel in prose. In this paper I will be focusing only on one such piece of poetry and prose, from two authors, István Domonkos (b. 1940) and László Végel (b. 1941), respectively. More precisely speaking, the subject of this paper are Domonkos's, today undoubtedly cultic poem, Kormányeltörésben (Rudderless), originally published in 1971, ands Végel's no less cultic novel, The Memoirs of a Pimp, published in 1967. It is exactly in these texts, where, in my opinion, the phenomenon of deliberate language loss as a specific and very conscious artistic method can be noticed in the most penetrant way. 
The position of Domonkos's lyrical subject in the poem Rudderness is that of a man who not only speaks in the non-standardized dialect of Hungarian spoken in Vojvodina, which, observed from a traditionally normative viewpoint, is kind of a "debauched" language, but also the position of a man who exists in some kind of "double language exile". We are talking about a man from the Vojvodina province in Yugoslavia (now Serbia), who a priori speaks a substandard dialect of his own mother tongue (Hungarian), which is, naturally, "contaminated" by Serbian influence on the level of vocabulary and even grammar sometimes. However, what makes his exile a "double" one is the fact that he is living the life of a Yugoslav economic emigrant ("Gastarbeiter") in Sweden (the poem was indeed written in the Swedish town of Djuphuilt in 1971), who, slowly, but surely, is starting to forget his Hungarian mother tongue, as well as Serbo-Croatian, the official and majority language of his ex-homeland, Yugoslavia. That, sometimes ridiculous, sometimes tragical and sometimes frightening "semi-language" spoken, or, rather, stuttered by Domonkos's lyrical subject, is, however, much more than a mere rhetorical decoration: in a way, with its crippled character, with its (dis)ability to only partially say things, it becomes the main character, the main protagonist, the hero of this subversive poem.

In order to achieve a convincing impression of such a "linguistic cripple" in a poem, however, the poet must be a genuine master of his mother tongue, states, quite rightly, Melinda Szarvas (2015: 19): "So, Ruderness seems to be the proof that, generally in literature, such a literary debauched, grammatically incorrect speech can be created only with the precise knowledge of language. This is, so to say, the sharpest paradoxon, the main contradiction of Domonkos's poem.". Moreover, reflecting on an observation by Gyöngyi Mikola, Szarvas states that Domonkos's play with the semi-illiterate ideological (communist) vocabulary and phrases, leads to a conclusion that the lyrical subject of this poem actually happens to be a disappointed communist party official, i.e. basically an intellectual, rather than an "ordinary" Gasterbeiter, a manual factory worker, for instance. Criticizing the fact that the critical discourse on this poem up to date has relied mostly on the perspectives of the "Gastarbeiter-narrative", Szarvas (2015: 18) notes that 
the personality of the subject speaking in the poem, and the whole poem built as a monologue is almost always interpreted from the perspective of the existential state of a guest-worker, albeit, if read carefully, the text itself leads to a conclusion that the lyrical speaker went to work abroad originally as an intellectual. Not only the literary, but also the historical and ideological allusions lead to this kind of conclusion.

Or, as Deleuze and Guattari would point out, the really significant writers who write in a minority language should, using the advantages of their own, linguistically and geographically marginalized language(s), reach the stadium in which they could achieve a certain kind of bilingualism in their own mother tongue. Roland Orcsik (2015: 43), following the paths of Derrida, Deleuze and Guattari, calls this paradox state, when ones' own mother tongue is felt as if it was a foreign language, "a centaur-like existential feeling of one's own language as a foreign one."

Domonkos's poem even today has not lost any of its historical relevance. One of the best proofs for this is the recent project, started by Péter Rácz, the head of the Hungarian Translators' House in the city of Balatonfüred, to translate this poem into as many languages as possible, and to publish it in the form of a multilingual book. It is interesting to notice that the current interpreters read this poem as a poem of the "all-time migrant" who has lost his own language, but has not found (and/or learned) a new one. Péter Rácz (2015: 7) points out that "this [is a] work of a debauched language, whose original can only be called Hungarian with the greatest stretch of the imagination". Rácz (2015: 7) notices that during the very project of translating this poem, "in so many ways, we demonstrated how existence thrown about all over the world is bruised by history, scraped, injured, cracked, split, falls apart and then is formed anew in its form that is poetically molded by a linguistic decay." Rácz (2015: 7) comes to an even more radical conclusion, almost in the style of Roland Barthes or Jacques Derrida, when he states that this poem "exists, in actual fact, simultaneously in many languages. It is completely by chance, however, that it was born in Hungarian more than forty years ago". Concerning the universality and today's re-actualization of this poem, Rácz (2015: 8) believes that the main reason for this can be found exactly in this debauched mother tongue, which symbolizes much more than just one concrete existential situation of a concrete Hungarian immigrant from Vojvodina in Sweden in the 70's: 
With the corruption of his own mother tongue (and with the poetic creation of a corrupted language), Domonkos signals the loss of identity that here, paradoxically, introduces not the Hungarian emigrant, immigrant and trans-migrant, but rather the migrant just in the process of losing his identity in his transitional linguistic confusion - anywhere in the world.

The same two important features of this poem are also noticed by the Hungarian scholar Beáta Thomka (2015: 208-209), who outlines that it could even be read in the light of the new and tragic wave of refugees coming to Europe mostly from the Middle East:

The vision taking as its point of departure the regional, minority, migrant basic condition has by today expanded to become universal. It is not even necessary to mention the several-million-strong flood of refugees appearing in international statistics in order to discern that the lamentation of Rudderless has ceased to be the monologue of the speaker's "I".

The specific "anti-aesthetics" of this undoubtedly iconic poem today is thus reflected in the rejection of the rules of classic versification as well as in the grammatical "mutilation" of the linguistic expression which seems to transmit a certain, today unquestionably even more strongly re-actualized existential experience of the foreignness around us and inside us, in a situation where the mother tongue is viewed as a foreign one. This existential experience is mediated (through the mouth of the lyrical subject, or the "lyrical antihero", whose grammar is not only simplified, but is in harsh collision with some basic rules of Hungarian grammar. Thomka (2015: 206) notices that

\begin{abstract}
the existential experience treats an uncommon, novel grammar, with an accumulation of infinitives and a staccato diction of robust rhythm. The distorted syntax of the verse, the omission of conjugation, and the nominal style become the source of a monotone musicality. [...] The absence of linguistic elements that ensure connection, and indicate linking and relationship (personal affixation, prefixes and suffixes, adverbs, signs of temporality) operates to heighten the effect, standing in opposition to the agglutinative system of the Hungarian language.
\end{abstract}

This consequent use of the infinitives leads to the creation of a certain, as Roland Orcsik (2015: 216), quoting Magdolna Danyi, calls it, 
"agrammatical linguistic model", and it is exactly this model which will become the main feature of the so-called "Gastarbeier-poetry" in the Vojvodina Hungarians' way. And it will be exactly this ruined, "unexpressive" or "partially expressive", "imprecise" language in which the poet will speak out about a terrifying existential state of specific apatrideness. Thomka (2015: 207) points out that "the surrender, risk, adversity, alienation and vulnerability that accompany the basic condition of me going abroad are concentrated into an epic poem. The 'ungrammatical' quality of the unconjugated infinitives and the ellipticality of the nominal style thus lift the loss of solid footing and uncertainty to a formal level."

As a practical illustration of the theses mentioned above, it could be useful to quote a relatively short passage from the initial situation of Domonkos's (2015: 26) poem Rudderness in the English translation by Owen Good:

me being

me no speaking magyar

living abroad life

money language national flag

national anthem postage stamp

presidents great leaders

rummaging for appropriate one

wherever $i$ arrive

we dying one and all

always on the wrong battlefield

our open skull the whisk's

handle sticks out

proletarians

of the world

contretarians

of the world

this being poem

Unlike poetry, in which, naturally, it is exactly this total linguistic reductionism, minimalism, the frequent use of ellipses and syncopas that 
make the feeling of language loss, in narrative prose, especially in novels, the writer is forced to use a somewhat different strategy and to choose from a different repertoire of linguistic tools. When Deleuze and Guattari write about the specific features of "small literatures", they do this by considering the works of Franz Kafka, i.e. a prominent prose writer. And although the historical, literary context and the thematics of Kafka's works and the works of the writer (László Végel) whose novel is analyzed in this paper, are obviously quite different, some most important observations of Deleuze and Guattari, especially those concerning some general and clearly not epoch-dependant features of the "small" or, in this case, of the "minor" literature, seem to stand very firmly.

From our point of view, especially relevant are those observations of Deleuze and Guattari, which address the problem of language. The language of each and every small literature, as Deleuze and Guattari (1998: 27) point out, "is marked with a strong coefficient of deterritorialization". Linguistic deterritorialization, as one of the key concepts of their understanding of the language of small literature(s), is primarily based on the need that the writer finds, through language, as Deleuze and Guattari (1998: 32) insist "his own point of retardation, his own dialect, his own third world, his own desert." The writer's task, however, is made much more difficult by the relative poorness of the vocabulary, which means that he must find a different level of language - the intensity - which would lead to an equally effective expression, according to Deleuze and Guattari (1998:33): "Since the vocabulary is poor, he will make it vibrate with intensity." In this respect, Deleuze and Guattari (1998: 39) underline the so-called inner intensity of words: "Making the lines vibrate, opening the words towards their unprecedented inner intensities, in other words, towards the non-signifying intensive use of the language."

In his first book from 1967, which is a kind of contemporary Bildungsroman, in the novel Egy makró emlékiratai [The Memoirs of a Pimp], László Végel is using the very reduced language of ethnic Hungarian students in Novi Sad, a language peppered with slang phrases. This language could, as a whole, however, scarcely be called even a slang-language. It seems to certify the above mentioned thesis of Deleuze and Guattari about the poorness of vocabulary being compensated for by the vibration of in- 
tensity. Végel's older contemporary, the outstanding Hungarian poet (from Hungary, i.e. a person who never got to live in a minority position) Sándor Weöres (1913-1989), even talks about the very strong impression of "verbal impotence" that Végel's fictitious figures made on him. In his 1968 letter to Végel, Sándor Weöres (2005: 197-198), with great enthusiasm underlines exactly the linguistic innovativeness of Végel's novel:

Your ability to create a new language is terrifying. This pimp-youth don't even have their own slang, argot, jargon, they are using a mortar-like, undecorated, colorless idiom, their vocabulary is small and unexpressive [...] your figures, in the lack of language, just yawn like fish [...] Their verbal impotence is horrifying. [...] you are torturing the language, and the more it suffocates and yawns, the less mercy you have for it. It's an acrobatic achievement, like dancing without legs: to shout without a language, so that my ears are ringing.

The language of Végel's protagonists, which can be noticed not only in the quite frequent dialogues, but also in the narration itself, since the narrator, who speaks in the first person singular, is himself a member of this young, student population, seems to be giving an affirmative answer to Deleuze and Guattari's (1998: 34) semirhetorical question, that one of the main problems of small literature, and probably one of the main problems of every modern writer, generally, is "how to become a nomad, immigrant and a Gypsy in one's own language?"

The (Yugoslav) writer Aleksandar Tišma, who translated Végel's novel into Serbian, talks about this book as the first novel coming from an author from Vojvodina - regardless of language - which did away with the complex of provinciality. Tišma (2005: 15) calls this novel the very first modern urban novel in Vojvodina:

The literature of Vojvodina, both that written in the languages of national minorities or that written in Serbian, is stigmatized by the complex of provinciality: on one hand, the ambition to reach and fit in the whole-Yugoslav context, on the other hand, to attract attention with its local colors and characteristics. There is not a trace of this complex in Végel's first book. [...] It is this feature, and not just the urban ambient, the street life, the asphalt as a symbol and the realistic tendencies that make The Memoires of a Pimp one of the very first urban novels in the literature of Vojvodina. 
This surpassing of the, until then, almost "obligatory" minority and peripheral narrative, Végel achieves neither by desperately trying to impose local colors, nor by striving for proper language use. On the contrary, he does this with a certain little "linguistic revolution", by creating a specific, very limited, very poor language, a language even poorer than the real language of the Novi Sad Hungarian youth of the time. With these radical and quite visible rejections and reductions, Végel, of course, seriously irritated his contemporary readers. Kornélia Faragó (2005: 37) notices that

concerning the language, he really didn't want to meet the expectations, especially those linguistic needs that could have had the potential of referentiality. It must have been irritating that he didn't want to strive neither for dialectological preciseness, nor for sociolinguistic reliability. "This language doesn 't exist” (Tomán).

The importance of language as a specific poetic trump is emphasized by the Slovenian scholar Jutka Rudaš as well. Rudaš (2005: 40) states that "Végel creates a picture of a world where the gap between the text and the referenciality is filled in by linguistic expression." The state of a certain "linguistic shock" in which the great poet and master of the Hungarian language Sándor Weöres found himself while reading Végel's book, could be, however, explained not only by the power of "verbal impotence" that Végel's figures emanate, but also by the essential contextual unintelligibility of Végel's language in comparison with the standard Hungarian language, or, more precisely speaking, concerning the cultural codes which are unintelligible to the Hungarian readers in Hungary. Rudaš (2005: 43) notes that

\footnotetext{
the Pimp is full of linguistic clichés, tropes that depend not on linguistic, but on cultural competence, more precisely speaking, on the formal aspect of cultural competence. I don't see this as the factor that reduces the aesthetical value of the work, on the contrary, it is the ecstasy, the magic of the foreign world that is unfolding through language, that is so mesmerizing. The unfamiliar attitude towards life and problems is expressed exactly through the Hungarian language.
}

This kind of language, as Rudaš (2005: 46) points out, filled "with lustful neologisms, words taken from Serbian, word for word translations, regionalisms, the slang of the Yugoslav Hungarians, is, all in all, an ironical 
language that is bearing a rhetorical surplus value." Rudaš notices that these everyday-words which Végel's narrator uses so frequently, taken individually wouldn't be of any outstanding artistic, literary value. These common words get this special value once they are cleverly mixed in the writer's masterful novelistic-linguistic combinatorics, states Rudaš (2005: 47):

\begin{abstract}
The vocabulary of Végel's poetics consists of commonly used words, which become unusual as a whole of their pictures, that is how they reflect the depth and uniqueness of the experience, it is not just the unique use of the words that makes the punchline, but the way they are put one beside the other. From the everyday functional vocabulary of a heterogeneous society/environment/ country Végel managed to create art.
\end{abstract}

However, a further explanation is needed here, considering some serious contradictions between some of the aforementioned opinions. Namely, this opinion by Jutka Rudaš somewhat contradicts the earlier cited statement by Kornélia Faragó, who remarked that Végel created a language that in reality doesn't even exist. Maybe the solution to this contradiction could be found in the aforementioned heterogeneous character of that language, in the very different and often mutually incompatible sources from which Végel presumably inspired himself in order to create this language. The mere fact that in not a single one of his numerous following books did Végel manage to surpass or even repeat this kind of linguistic mastery is probably the best proof of the complexity and difficulty of this kind of a writing task. And, more generally speaking, probably the best proof of the significance and the difficult character of Végel's and Domonkos's linguistic undertaking (which, from this historical distance, cannot be labeled as a "merely" linguistic, neo-avant-garde experiment) lies in the fact that after them there have been indeed very few artists who came even near to their achievement of creating really great pieces of art from the broken pieces of an "impoverished", partly sub-standard minority language.

\title{
References:
}

Bányai J., "Valóban mi lesz velünk”. Forrás, Kecskemét, 2015/6, pp. 56-60. Deleuze, G. - Guattari, F., Kafka. Serbian translation by Slavica Miletić. Izdavačka knjižarnica Zorana Stojanovića, Sremski Karlovci - Novi Sad, 1998. 
Domonkos I., Kormányeltörésben. Országos Idegennyelvü Könyvtár Napkút Kiadó, Budapest, 2015.

Faragó K., “Interpretációs ösvények kereszteződésében”. In: Virág Z. (ed.), Végel-Symposion. Tanulmányok Végel László müveiről. Kijárat Kiadó, Budapest, 2005, pp. 30-39.

Orcsik R., detoNáció. Domonkos István müvészetének exjugoszláv irodalmi kapcsolatformái. Forum Könyvkiadó, Újvidék [Novi Sad], 2015.

Rácz P., "A translator comes upon the shards of a broken vessel". Translated by Adele Eisenstein. In: Domonkos, I., Kormányeltörésben, Budapest, 2015, pp. 7-8.

Rudaš, J., "A szellem finom játéka (Az Egy makró emlékiratai Esterházy Péter Függőjében)". In: Virág Z. (ed.), Végel-Symposion. Tanulmányok Végel László müveirôll. Budapest, 2005, pp. 40-52.

Szarvas M., “ 'én nem látni sehol határ / én látni új látóhatár' (Domonkos István: Kormányeltörésben)”. In: Forrás, Kecskemét, 2015/6, pp. $14-26$.

Thomka B., "The Poetics of Expatriation". Transl. by Adele Eisenstein. In: Domonkos, I., Kormányeltörésben, Budapest, 2015, pp. 203-213.

Tišma, A., "Egy makró emlékiratai". Hungarian translation by Beáta Végel. In: Virág Z. (ed.), Végel-Symposion. Tanulmányok Végel László müveiröl. Budapest, 2005, pp. 13 -15.

Végel L., Egy makró emlékiratai. Jelenkor Kiadó, Pécs, 2009.

Weöres S., "Weöres Sándor levele Végel Lászlóhoz". In: Virág Z. (ed.), Végel-Symposion. Tanulmányok Végel László müveiről. Budapest, 2005, pp. 197-200.

\begin{abstract}
There are basically two different attitudes towards the use of language in minority literatures. The first and more conservative one, is marked by the ambition to conserve the "threatened" language, while the other, which is found mostly in modern and contemporary works, is trying, in a somewhat paradoxical manner, to create its world by using a brand new, seemingly "poor" and restricted language created from the elements of the common language used in the minority community. This language, however, sometimes has little or almost nothing to do with the "real", spoken language of the members of
\end{abstract}


the given community. This paper deals with this phenomenon of "deliberate loss of language" in two iconic works by the Hungarian poet from Vojvodina, István Domonkos and the prose writer from Vojvodina, László Végel. The paper also tries to underline the main differences in the manifestation of this phenomenon in poetry and in prose.

Keywords: minority literature, deliberate language loss

\section{Biographical statement}

MARKO ČUDIĆ (born in Senta in 1978) is an Assistant Professor at the Faculty of Philology, Dept. Of Hungarian Literature, Language and Culture at the University of Belgrade, where he teaches Modern and Contemporary Hungarian Literature, Theory and Technique of Literary Translation, as well as a specialized course for master students, The Poetics of Dezső Kosztolányi. He has published two books so far (Danilo Kiš i moderna mađarska poezija, Plato, Beograd, 2014 and Uvod u poetiku romana putovanja, Plato, Beograd, 2014) and several scientific papers, articles and essays in Serbia and abroad (mostly in Hungary). He has participated in several international scientific conferences. His main fields of interest include the contacts of Serbian and Hungarian literature, theory of genres and theory of literary translation. He is also an active literary translator and has translated eleven books so far. His translations include the works of Dezső Kosztolányi, Péter Hajnóczy, Ottó Tolnai, László Krasznahorkai, Viktória Radics and others.

E-mail: marko.cudic@gmail.com 